\title{
A prospective, cross-sectional study of anaemia and peripheral iron status in antiretroviral naïve, HIV-I infected children in Cape Town, South Africa

\author{
Brian S Eley*1, Alan A Sive ${ }^{1}$, Margaret Shuttleworth ${ }^{2}$ and Gregory D Hussey ${ }^{1}$
}

Address: ${ }^{1}$ School of Child and Adolescent Health, University of Cape Town and Red Cross Children's Hospital, Private Bag, Rondebosch, 7700, South Africa and ${ }^{2}$ Department of Paediatric Haematology, Division of Pathology, University of Cape Town and Red Cross Children's Hospital, Private Bag, Rondebosch, 7700, South Africa

E-mail: Brian S Eley* - beley@ich.uct.ac.za; Alan A Sive - alan.sive@jcu.edu.au; Margaret Shuttleworth - mshuttle@pawc.wcape.gov.za; Gregory D Hussey - ghussey@rmh.uct.ac.za

${ }^{*}$ Corresponding author

Published: II February 2002

BMC Infectious Diseases 2002, 2:3
Received: 22 August 2001

Accepted: II February 2002

This article is available from: http://www.biomedcentral.com/I47/-2334/2/3

(C) 2002 Eley et al; licensee BioMed Central Ltd. Verbatim copying and redistribution of this article are permitted in any medium for any purpose, provided this notice is preserved along with the article's original URL.

\begin{abstract}
Background: Anaemia is a common manifestation of paediatric HIV infection. Although there are many causes, anaemia of chronic diseases is the most frequent type. In poor countries iron deficiency is widespread. It is probable that many HIV-infected children in these countries are also iron deficient. This study describes the relationship between paediatric HIV infection and anaemia, and documents the peripheral iron status of antiretroviral naive, HIV-infected children.
\end{abstract}

Methods: Sixty children were evaluated prospectively. Investigations included CD4+ count, haemoglobin concentration $(\mathrm{Hb})$, red blood cell $(\mathrm{RBC})$ morphology, and iron studies.

Results: Anaemia was present in $73 \%$ of children. Compared to mild HIV infection, median $\mathrm{Hb}$ was lower in children with moderate clinical infection $(104 \mathrm{~g} / \mathrm{L} v \mid \mathrm{I} 2 \mathrm{~g} / \mathrm{L}, \mathrm{p}=0.04)$ and severe clinical infection $(96 \mathrm{~g} / \mathrm{L} \vee 1 / 2 \mathrm{~g} / \mathrm{L}, \mathrm{p}=0.006)$, and more children with severe infection were anaemic $(92 \%$ $\checkmark 58 \%, 0.04$ ). There was a significant relationship between immunological status and $\mathrm{Hb} .68 \%$ had abnormal RBC morphology. Significantly more children with moderate and severe disease, and severe immunosuppression had abnormal RBC morphology. $52 \%$ were iron-depleted, $20 \%$ had iron-deficient erythropoiesis and 18\% iron deficiency anaemia (IDA). 16\% (7/44) of anaemic children had microcytosis and hypochromia. Median soluble transferrin receptor concentration was significantly higher in those with microcytic hypochromic anaemia $(42.0 \mathrm{nmol} / \mathrm{L} v 30.0 \mathrm{nmol} / \mathrm{L}$, $\mathrm{P}=0.008)$.

Conclusions: Both the proportion of anaemic children and the median $\mathrm{Hb}$ were associated with disease status. Iron depletion and IDA are major problems in HIV-infected children in South Africa.

\section{Background}

Anaemia is a common manifestation of paediatric HIV infection and is a significant negative predictor of survival $[1,2]$. Although there are many causes of HIV-associated anaemia, anaemia of chronic diseases (ACD) is the most frequent type [3], inflammatory cytokines released during chronic diseases inhibit erythropoiesis, blunt the erythropoietin response, reduce red blood cell survival and pre- 
vent the release of iron from the reticuloendothelial system, leading to the development of ACD [3,4].

Iron deficiency is widespread in children in developing countries. A recent nutritional survey showed that approximately $20 \%$ of South African children were anaemic and $10 \%$ iron deficient. In this survey HIV status was not recorded [5]. Another study conducted on Italian children documented iron deficiency, caused by intestinal malabsorption, in a large proportion of HIV-infected children [6]. Because of the high prevalence of iron deficiency among South African children, it is probable that many HIV-infected children are also iron deficient. This report documents the relationship between paediatric HIV infection and anaemia and describes the peripheral iron status of HIV-infected children in an economically deprived setting.

\section{Methods}

A prospective, cross-sectional study was performed on 60 clinically stable, antiretroviral naïve, HIV-infected children attending the HIV clinic at Red Cross War Memorial Children's Hospital in Cape Town. The ambulatory management of children who attend the clinic includes cotrimoxazole prophylaxis, treatment of minor infections and nutritional and micronutrient supplementation. Antiretroviral therapy is not routinely administered to HIV-infected children in South Africa. Children were considered eligible for inclusion if they were relatively well i.e. they had had no acute illness or febrile episode in the preceding 7 days, nor hospitalised in the preceding 14 days. Children were excluded if they were acutely ill. The first 2 or 3 children seen at each weekly clinic over an 8 month period were enrolled, after their parents were counselled and written consent obtained. The Research Ethics Committee of the University of Cape Town approved the study.

Children were diagnosed and classified into clinical and immunological categories according to CDC criteria [7]. CD4+ lymphocyte counts were measured on EDTA-anticoagulated whole blood samples using an EPICS Profile II flow cytometer (Coulter Corporation, Hialeah, Florida) [8]. Haemaglobin concentration (Hb), red blood cell (RBC) indices [mean corpuscular volume (MCV), mean corpuscular haemaglobin $(\mathrm{MCH})$, mean corpuscular haemaglobin concentration (MCHC) and red blood cell distribution width (RDW)] and RBC morphology were determined on EDTA-anti-coagulated blood samples using a Coulter MAXM (Coulter Corporation), according to the manufacturer's instructions. Red blood cell morphology was validated by light microscopy, on May Grunewald Giemsa stained samples [9].

Evaluation of iron status was performed on heparinised plasma. Ferritin concentration was measured by commer- cial immunoassay (Spectro Ferritin ${ }^{\circledR}$, Ramco laboratories, Houston, Texas), iron concentration (Fe) by direct spectrophotometry on a RA 1000 analyser, model TM34E1120/115CV (Bayer - Technicon Instruments Corporation, New York) using a commercial kit (MPR Iron without deproteinisation, Roche Diagnostics Corp., Indianapolis), and transferrin concentration by nepholometry on a Behring nepholometer, model BN 100 with commercial antisera (Behringwerke AG, Marburg, Germany). Total iron binding capacity (TIBC) was calculated using the formula: TIBC $(\mu \mathrm{g} / \mathrm{dl})=($ Transferrin $\times 200) \div 8$ [10]. Transferrin saturation (TS) was determined as follows: TS $=$ (Plasma iron concentration $\div$ TIBC) $\times 100$ [11]. Results were compared to locally derived normal age-related values. The following definitions were used in the analysis (i) iron depletion: ferritin $<10 \mu \mathrm{g} / \mathrm{L}$, (ii) iron-deficient erythropoiesis: ferritin $<10 \mu \mathrm{g} / \mathrm{L}$ and at least 3 of the following criteria: $\mathrm{Fe}<8.8 \mu \mathrm{mol} / \mathrm{L}$, TIBC $>$ $71.6 \mu \mathrm{mol} / \mathrm{L}, \mathrm{TS}<10 \%$, MCV less than normal age-related values and $\mathrm{MCH}$ less than normal age-related values, and (iii) iron deficiency anaemia (IDA): criteria for iron-deficient erythropoiesis plus Hb less than the normal age-related range $[12,13]$. Soluble transferrin receptor concentration (sTfR.) was measured on serum samples using a commercial immunoassay (Quantikine ${ }^{\mathrm{TM}} \mathrm{IVD}^{\mathrm{TM}} \mathrm{sTfR}$. assay, R\&D Systems, Minneapolis, Minnesota). Soluble transferrin receptor concentration results were used in the comparative analyses.

Data was collated and analysed using Epi Info version 6.04, Division of Surveillance and Epidemiology, CDC, Atlanta, Georgia. Categorical and continuous data were compared using the Chi-squared and Kruskal Wallis tests respectively. The Spearman rank correlation test was used to determine the relationship between different continuous variables. A p value $<0.05$ was considered significant.

\section{Results}

The median age (quartiles) was 25.0 months $(13.0,37.8)$. The male to female ratio was 1.0:0.9. The diagnosis of HIV infection was established by polymerase chain reaction in $73 \%(44 / 60)$ i.e. children less than 18 months of age and by ELISA in $27 \%(16 / 60)$ i.e. children more than 18 months of age. Mild clinical features of HIV infection (Category A) were present in 32\% (19/60), moderate features (Category B) in 48\% (29/60) and severe features (Category C) in 20\% $(12 / 60)$. Twenty per cent $(12 / 60)$ had no evidence of immunosuppression (Category I), $35 \%(21 / 60)$ were moderately immunosuppressed (Category II) and 45\% (27/60) were severely immunosuppressed (Category III). The median age was significantly lower in category $\mathrm{C}$ when compared to category A (13.5 months $v 28.0$ months, $\mathrm{p}=0.03)$ and category $\mathrm{B}(13.5$ months $\mathrm{v} 30$ months, $\mathrm{p}=0.02$ ). There was no significant age differences between the immunological categories. 
Table I: Laboratory measurements of iron status $(n=60)$

\begin{tabular}{llll}
\hline Variable & Median concentration (quartiles) & Percentage below normal age-range & Percentage above normal age-range \\
\hline $\mathrm{Hb}(\mathrm{g} / \mathrm{L})$ & $104(96, \mathrm{III})$ & 73 & 2 \\
$\mathrm{MCV}(\mathrm{fL})$ & $76.4(74.1,80.5)$ & 20 & 0 \\
$\mathrm{MCH}(\mathrm{pg})$ & $26.3(24.6,27.7)$ & 20 & 2 \\
$\mathrm{MCHC}(\mathrm{g} / \mathrm{dL})$ & $34.3(33.4,35.0)$ & 0 & 0 \\
$\mathrm{RDW}(\%)$ & $16.2(14.9,17.6)$ & 0 & 2 \\
Ferritin $(\mu \mathrm{gg} / \mathrm{L})$ & $9.0(4.9,36.5)$ & $52^{*}$ & 2 \\
Iron $(\mu \mathrm{mol} / \mathrm{L})$ & $4.0(2.1,7.7)$ & 75 & 0 \\
Transferrm $(\mathrm{g} / \mathrm{L})$ & $2.6(2.2,2.9)$ & 32 & 33 \\
TIBC $(\mu \mathrm{mol} / \mathrm{L})$ & $65.4(55.4,74.7)$ & 0 & 0 \\
TS $(\%)$ & $6.0(4.1,10.7)$ & $70^{+}$ &
\end{tabular}

* Per cent $<10 \mu \mathrm{g} / \mathrm{L}$, Per cent $<10 \%$

Seventy three per cent $(44 / 60)$ were anaemic by age-related reference values. The median $\mathrm{Hb}$ was $104 \mathrm{~g} / \mathrm{L}$ (96, 110). Seventy two per cent had a Hb less than $110 \mathrm{~g} / \mathrm{L}$. Two children had a Hb less than $80 \mathrm{~g} / \mathrm{L}$. Compared to Category A, the median $\mathrm{Hb}$ was significantly lower in Category B $(104 \mathrm{~g} / \mathrm{L} v 112 \mathrm{~g} / \mathrm{L}, \mathrm{p}=0.04)$ and Category C $(96 \mathrm{~g} / \mathrm{L}$ $\mathrm{v} 112 \mathrm{~g} / \mathrm{L}, p=0.006)$. Compared to Category A, more children in Category C were anaemic $(92 \% v 58 \%, p=0.04)$. The proportion of children with anaemia in Category $\mathrm{B}$ was greater than Category A $(76 \% v 58 \%, \mathrm{p}=0.2)$, but this was not significant. Median $\mathrm{Hb}$ was significantly lower in Category III compared to Category I $(99 \mathrm{~g} / \mathrm{Lv} 110 \mathrm{~g} / \mathrm{L}, \mathrm{p}=$ $0.003)$. The median $\mathrm{Hb}$ was lower in Category II than in Category I $(104 \mathrm{~g} / \mathrm{L} v 110 \mathrm{~g} / \mathrm{L}, \mathrm{p}=0.07)$, but this was not significant. Compared to Category I, more children in Category II $(76 \% v 42 \%, \mathrm{p}=0.04)$ and Category III ( $85 \%$ $v 42 \%, \mathrm{p}=0.005$ ) were anaemic. Median $\mathrm{Hb}$ did not correlate with age $(\mathrm{r}=0.35,95 \%$ confidence interval-0.14, $0.36)$.

Many children had abnormal RBC indices and altered peripheral iron results (Table 1I). Red blood cell morphology showed anisocytosis in $68 \%(41 / 60)$, polychromasia in $17 \%(10 / 60)$, target cells in $15 \%(9 / 60)$ and microcytosis plus hypochromia in $12 \%(7 / 60)$. Thirty two per cent $(19 /$ $60)$ had normal RBC morphology. In comparison to Category A more children in Category B $(76 \% v 42 \%$, $\mathrm{p}=$ $0.006)$ and Category C disease $(92 \% v 42 \%, \mathrm{p}=0.02)$ had abnormal RBC morphology. Significantly more children in Category III than Category I had abnormal morphology $(89 \% v 42 \%, \mathrm{p}=0.002)$. A larger proportion in Category II had abnormal morphology relative to Category I ( $67 \%$ $v 42 \%, \mathrm{p}=0.4)$; this difference was not statistically significant.

Fifty two per cent $(31 / 60)$ of the children were iron-depleted, $18 \%(11 / 60)$ had iron-deficient erythropoiesis and $17 \%(10 / 60)$ IDA. Of the 11 patients with iron-deficient erythropoiesis 2 fulfilled all diagnostic criteria, 3 fulfilled 4 criteria and 6 fulfilled 3 criteria. Forty five per cent $(20 / 44)$ of all anaemic children were iron-depleted. Table 2II compares anaemic children with low plasma ferritin concentrations and those with ferritin concentrations $>10$ $\mu \mathrm{g} / \mathrm{L}$. With exception of transferrin and TIBC, measures of iron status are not significantly different between the two groups. Thirteen per cent $(8 / 60)$ of the anaemic children had a ferritin concentration greater than $100 \mu \mathrm{g} / \mathrm{L}$. Children with microcytic, hypochromic anaemia had significantly higher sTfR. The ferritin concentration of these children ranged from $4.9 \mu \mathrm{g} / \mathrm{L}$ to $49 \mu \mathrm{g} / \mathrm{L}$. Four of these seven children had a ferritin concentration $<10 \mu \mathrm{g} / \mathrm{L}$. Other measures of iron status were not significantly different between the groups of children with or without microcytic, hypochromic anaemia (Table 3III). Median sTfR was significantly higher in category $\mathrm{C}$ compared to category A $(35.5 \mathrm{nmol} / \mathrm{L} v 26.0 \mathrm{nmol} / \mathrm{L}, \mathrm{p}=0.01)$. There was no association between sTfR and immunological category.

\section{Discussion}

A large number of stable, HIV-infected children were anaemic. Few had severe anaemia. Furthermore, both the proportion of children with anaemia and median haemaglobin concentration were associated with clinical and immunological status. There was no association between $\mathrm{Hb}$ and chronological age. Studies of infected children and adults indicate that anaemia independently predicts poor outcome $[2,14,15]$. The results of the present study are in agreement with these observations, as significantly more children with severe clinical features and severe immunosuppression were anaemic.

Many children had abnormal red blood cell morphology. Anisocytosis was the most frequent observation. It usually correlates with an increased red blood cell distribution 
Table II: Comparison of anaemic children with plasma ferritin concentration < $10 \mu \mathrm{g} / \mathrm{L}$ (Group A) or $\geq 10 \mu \mathrm{g} / \mathrm{L}$ (Group B)

\begin{tabular}{|c|c|c|c|}
\hline Variable & Group A $(n=20)$ Median (quartiles) & Group B $(n=24)$ Median (quartiles) & $P$ value \\
\hline $\mathrm{Hb}(\mathrm{g} / \mathrm{L})$ & $103(97,108)$ & $95(87,104)$ & 0.04 \\
\hline $\mathrm{MCV}(\mathrm{fL})$ & $75.2(7 I .4,78.6)$ & $76.3(71.9,81.6)$ & 0.3 \\
\hline $\mathrm{MCH}(\mathrm{pg})$ & $25.6(23.5,26.4)$ & $26.3(24.2,28.3)$ & 0.2 \\
\hline $\mathrm{MCHC}(\mathrm{g} / \mathrm{dL})$ & $33.6(32.9,34.3)$ & $34.2(33.2,34.3)$ & 0.2 \\
\hline RDW (\%) & $17.0(16.1,18.1)$ & $16.6(15.4,17.8)$ & 0.7 \\
\hline Ferritin $(\mu g / L)$ & $4.9(4.9,7.0)$ & $46.5(23.5,117)$ & $<0.001$ \\
\hline Iron $(\mu \mathrm{mol} / \mathrm{L})$ & $3.7(2.0,5.7)$ & $3.2(2.0,6.9)$ & 0.8 \\
\hline Transferrm (g/L) & $2.9(2.5,3.1)$ & $2.2(1.9,2.6)$ & $<0.001$ \\
\hline $\mathrm{TIBC}(\mu \mathrm{mol} / \mathrm{L})$ & $71.5(63.4,78.2)$ & $54.9(46.5,65.9)$ & $<0.001$ \\
\hline TS (\%) & $4.9(3.5,7.3)$ & $5.1(4.1,10.1)$ & 0.5 \\
\hline sTfR (nmol/L) & $32.0(29.3,38.5)$ & $30.0(22.8,39.0)$ & 0.3 \\
\hline
\end{tabular}

Table III: Comparison of anaemic children with (Group I) or without (Group II) microcytosis plus hypochromia

\begin{tabular}{lllc}
\hline Variable & Group I $(\mathrm{n}=7)$ Median (quartiles) & Group II $(\mathrm{n}=37)$ Median (quartiles) & $P$ value \\
\hline & & & \\
$\mathrm{Hb}(\mathrm{g} / \mathrm{L})$ & $96(87,99)$ & $101(94,105)$ & 0.2 \\
$\mathrm{MCV}(\mathrm{fL})$ & $67.2(65.2,68.2)$ & $76.4(74.6,81.0)$ & $<.001$ \\
$\mathrm{MCH}(\mathrm{pg})$ & $22.0(21.1,23.2)$ & $26.2(25.0,27.8)$ & $<0.001$ \\
$\mathrm{MCHC}(\mathrm{g} / \mathrm{dL})$ & $33.1(32.6,34.1)$ & $34.2(33.4,34.6)$ & 0.08 \\
RDW $(\%)$ & $16.8(16.2,18.0)$ & $16.6(15.2,18.0)$ & 0.4 \\
Ferritin $(\mu \mathrm{g} / \mathrm{L})$ & $8.0(4.9,38.0)$ & $15.0(5.0,87)$ & 0.3 \\
Iron $(\mu \mathrm{mol} / \mathrm{L})$ & $2.7(2.0,6.5)$ & $3.5(2.0,5.7)$ & 0.8 \\
Transferrm $(\mathrm{g} / \mathrm{L})$ & $2.8(2.6,3.1)$ & $2.6(2.0,2.9)$ & 0.1 \\
TIBC $(\mu \mathrm{mol} / \mathrm{L})$ & $69.3(64.5,77.5)$ & $63.8(50.5,73.0)$ & 0.1 \\
TS $(\%)$ & $3.7(2.9,9.0)$ & $5.2(4.1,9.0)$ & 0.1 \\
sTfR $(\mathrm{nmol} / \mathrm{L})$ & $42.0(35.0,45.0)$ & $30.0(25.0,36.0)$ & 0.008 \\
& & & \\
\hline
\end{tabular}

width [16], present in many children. Anisocytosis is a non-specific feature that may be present in any red blood cell disorder, including IDA and ACD [17]. Interestingly, there was a statistically significant relationship between disease status and red blood cell morphology. More children with severe clinical disease and severe immunosuppression had abnormal morphology. These findings were similar to the relationship between disease status and anaemia, and reflect the connection between abnormal morphology and anaemia.

Distinguishing IDA from ACD in chronic inflammatory diseases may be a problem, as many of the laboratory measurements used to evaluate iron status are affected in a similar manner [18]. Ferritin concentration remains the most practical measurement for evaluating iron stores. A low concentration $(<10 \mu \mathrm{g} / \mathrm{L})$ unequivocally identifies iron-depleted stores. Ferritin is an acute phase reactant.
Therefore, levels may be falsely normal in chronic inflammatory diseases such as HIV infection, despite the presence of iron depletion $[12,13]$. Elevated ferritin levels, often exceeding $1000 \mu \mathrm{g} / \mathrm{L}$ have been recorded in adults with acquired immunodeficiency syndrome [3]. In the present study, 45\% (20/44) of all anaemic children were iron-depleted. A comparison of the laboratory results of anaemic children with or without hypoferritinaemia (Table 2II) showed few statistically significant differences between the two groups. In particular, sTfR was not significantly different between the two groups. Failure to show a clear distinction between these groups confirms the complex relationship between iron depletion, iron deficiency anaemia and anaemia of chronic disorders in HIV infection.

The present study employed strict criteria to identify children with IDA. These criteria were adapted from previous- 
ly published guidelines. Although locally derived normal age-related values were taken into consideration the criteria were similar to those used internationally $[12,13]$. The results probably under-represent the true extent of IDA. For example, only four children with microcytic, hypochromic anaemia had low ferritin concentrations. They were included in the IDA group. The other three with microcytic, hypochromic anaemia were excluded, although they had significantly elevated soluble transferrin receptor concentrations, in keeping with IDA (Table 3III). Despite these omissions, the results suggest that IDA is more prevalent in HIV-infected children than in the general paediatric population in South Africa [5].

Soluble tranferrin receptor is not an acute phase reactant. It is considered more reliable than ferritin to distinguish IDA from ACD in acute and chronic inflammatory diseases. In IDA sTfR is elevated and in ACD sTfR remains normal $[13,18]$. In the present study, sTfR of anaemic children with or without hypoferrritinaemia were not significantly different. However, those with microcytic, hypochromic anaemia had significantly elevated sTfR. The results suggest that many HIV-infected children with anaemia probably have a combination of ACD and iron depletion, a smaller proportion have IDA and some children with normal ferrritin concentrations have IDA. Only those with classic findings of IDA had predictably high soluble transferrin receptor concentrations.

The biggest weakness of the present study was the failure to compare the iron status of HIV-infected children with non-HIV-infected controls. However, iron depletion was widespread, and IDA was far more prevalent than was documented in a recent national study of more than 6000 South African children [5]. That study was undertaken in 1994, when the prevalence of paediatric HIV infection was low [19]. The findings of the present study were comparable to results obtained in an Italian study evaluating iron status in HIV-infected children. In the Italian study iron deficiency, defined as low serum iron concentration, was present in $48 \%$ of HIV-infected children. The present study employed stricter criteria to define iron status. Therefore we can conclude that iron depletion and IDA are significant problems in HIV-infected children in South Africa.

Many aetiological factors probably contribute to the development of low iron status in HIV-infected children, including reduced dietary intake, the quality of dietary iron and altered iron absorption [20]. The Italian study showed that intestinal malabsorption is a major factor [5]. Whether iron therapy causes deleterious effects in paediatric HIV infection has not been established. In general, while the relationship between infection and iron status remains contentious, iron overload is associated with in- creased susceptibility to certain infections [21]. Therefore, liberal iron therapy or prophylaxis in HIV-infected children may facilitate the development of opportunistic infections. For the present time, HIV-infected children with IDA should receive therapeutic iron replacement. However, more research is required to establish the benefits and or deleterious effects of iron therapy and prophylaxis in antiretroviral naive, HIV-infected children, particularly those with iron depletion.

\section{Abbreviations \\ ACD Anaemia of chronic diseases}

EDTA Ethylene diamine tetra-acetic acid

CDC Centers for Disease Control

Fe Iron concentration

Hb Haemaglobin concentration

HIV-1 Human immunodeficiency virus - type 1

IDA Iron deficiency anaemia

MCH Mean corpuscular haemaglobin

MCHC Mean corpuscular haemaglobin concentration

MCV Mean corpuscular volume

RBC Red blood cell

RDW Red blood cell distribution width

sTfR Soluble transferrin receptor concentration

TIBC Total iron binding concentration

TS Transferrin saturation

\section{Competing interests}

None declared.

\section{Acknowledgements}

The Brodie Trust funded the project. Dr Eley was a recipient of a Research Fellowship from the Medical Research Council of South Africa. E.J. Hughes, G. Kossew, L. Abelse, A. van Schalkwyk and I. Mardarowicz are acknowledged for technical support.

\section{References}

I. Hilgartner M: Hematologic manifestations in HIV-infected children. J Pediatr 1991, I I 9:S47-S49

2. Tovo P-A, de Martino M, Gabiano C, Cappello N, D'Elia R, Loy A, Plebani A, Zuccotti GV, Dallacasa P, Ferraris G, et al: Prognostic factors and survival in children with perinatal HIV-I infection. Lancet 1992, 339:1249-1253 
3. Coyle TE: Hematologic complications of human immunodeficiency virus infection and the acquired immunodeficiency syndrome. Med Clin N Am 1997, 81:449-470

4. Allen UD, King SM, Gomez MP, Lapointe N, Forbes JC, Thorne A, MKirby A, Bowker J, Raboud J, Singer J, et al: Serum immunoreactive erythropoeitin levels and associated factors amongst HIV-infected children. AIDS 1998, I 2: |785- I79 |

5. South African Vitamin A Consultative Group (SAVACG): Anthropometric, vitamin $A$, iron and immunisation coverage status in children aged 6-7I months in South Africa, 1994. S Afr Med J 1996, 86:354-357

6. Castaldo A, Tarallo L, Palomba E, Albano F, Russo S, Zuin G, Buffardi $F$, Guarino A: Iron deficiency and intestinal malabsorption in HIV disease. J Pediatr Gastroenterol Nutr 1996, 22:359-363

7. Centers for Disease Control and Prevention, Division of HIVIAIDS: 1994 revised classification system for human immunodeficiency virus infection in children under 13 years of age. MMWR 1994, 43(RR-I 2): I- 10

8. Centers for Disease Control and Prevention, Division of HIVIAIDS: 1994 revised guidelines for the performance of CD4+ T-cell determinations in persons with HIV infection. MMWR 1994, 43(RR-3): $|-2|$

9. Dacie JV, Lewis SM: Practical Haematology Churchhill Livingstone 1995

10. Fielding J: Iron. Methods in Hematology 1980 I5-43

II. Burtis CA, Ashwood ER: Tietz Textbook of Clinical Chemistry Philidelphia: WB Saunders 1986

12. Wharton BA: Iron deficiency in children: detection and prevention. BrJ Haematol 1999, 106:270-280

13. Cook JD: Defining optimal body iron. Proceedings of the Nutrition Society 1999, 58:489-495

14. Forsyth BWC, Andiman WA, O'Connor T: Development of a prognosis-based clinical staging system for infants infected with human immunodeficiency virus. J Pediatr 1996, I 29:648655

15. Sullivan PS, Hanson DL, Chu SY, Jones JL, Ward JW, and the Adult/ Adolescent Spectrum of Disease Group: Epidemiology of anaemia in human immunodeficiency virus (HIV)-infected persons: results from the Multistate Adult and Adolescent Spectrum of HIV Disease surveillance Project. Blood 1998, $9 \mathrm{I}: 30 \mathrm{I}-308$

16. Perkocha LA, Rodgers GM: Hematologic aspects of human immunodeficiency virus infection: laboratory and clinical considerations. Am J Hematol 1988, 29:94-105

17. Hardistry RM, Weatherall DJ: Blood and its disorders Blackwell Scientific Publications 1982

18. Feelders RA, Kuiper EPA-Kramer, van Eijk HG: Structure, function and clinical significance of transferrin receptors. Clin Chem Lab Med 1999, 37:1-10

19. Department of Health of South Africa: Fifth national HIV survey in women attending antenatal clinics of the public health services in South Africa. Epidemiological Comments 1995, 22(4):90- 100

20. Olivares M, Walter T, Hertrampf E, Pizarro F: Anaemia and iron deficiency disease in children. Br Med Bull I 999, 55:534-543

21. Oppenheimer SJ: Iron and infection in the tropics: paediatric clinical correlates. Ann Trop Paediatr 1998, 18:S8I-S87
Publish with BioMed Central and every scientist can read your work free of charge

"BioMedcentral will be the most significant development for disseminating the results of biomedical research in our lifetime."

Paul Nurse, Director-General, Imperial Cancer Research Fund

Publish with BMC and your research papers will be:

- available free of charge to the entire biomedical community

- peer reviewed and published immediately upon acceptance

- cited in PubMed and archived on PubMed Central

- yours - you keep the copyright

Submit your manuscript here:

http://www.biomedcentral.com/manuscript/
BioMedcentral.com editorial@biomedcentral.com 